\title{
Bee Mix Antigen IgG4 Antibody Measurement
}

National Cancer Institute

\section{Source}

National Cancer Institute. Bee Mix Antigen Ig G4 Antibody Measurement. NCI Thesaurus.

Code C130118.

A measurement of the bee mix antigen IgG4 antibody in a biological specimen. 